\title{
ERRATUM
}

\section{Erratum to: On secondary new particle formation in China}

\author{
Markku KULMAMA (ه) ${ }^{1}$, Tuukka Petäjä ${ }^{1,2}$, Veli-Matti KERMINEN ${ }^{1}$, Joni KUJANSUU ${ }^{1}$, \\ Taina RUUSKANEN ${ }^{1}$, Aijun DING ${ }^{2,3}$, Wei NIE ${ }^{1,2,3}$, Min $\mathrm{HU}^{4}$, Zhibin WANG $^{4,5}$, Zhijun $\mathbf{W U}^{4}$, Lin WANG \\ Douglas R. WORSNOP ${ }^{1,7}$
}

(C) Higher Education Press and Springer-Verlag Berlin Heidelberg 2016

Erratum to: Front. Environ. Sci. Eng. 2016, 10(5): 08

DOI 10.1007/s11783-016-0850-1

The original version of this article unfortunately contained a mistake. The spelling of the first author's name was incorrect. Markku KULMAMA should be Markku Kulmala. The correct author list is given below:

Markku Kulmala(凶) ${ }^{1}$, Tuukka Petäjä ${ }^{1,2}$, Veli-Matti Kerminen ${ }^{1}$, Joni Kujansuu ${ }^{1}$, Taina Ruuskanen ${ }^{1}$, Aijun Ding ${ }^{2,3}$, Wei $\mathrm{Nie}^{1,2,3}$, Min $\mathrm{Hu}^{4}$, Zhibin Wang ${ }^{4,5}$, Zhijun Wu ${ }^{4}$, Lin Wang ${ }^{6}$, Douglas R. Worsnop ${ }^{1,7}$

The original article was corrected.

The online version of the original article can be found at http://dx.doi.org/10.1007/s11783-016-0850-1 